\title{
Yield Loss in Garlic Caused by Leek yellow stripe virus Argentinean Isolate
}

P. Lunello, Instituto de Fitopatología y Fisiología Vegetal, Instituto Nacional de Tecnología Agropecuaria (IFFIVEINTA) Camino 60 cuadras km 5,5 (5119) Córdoba, Argentina; J. Di Rienzo, Facultad de Ciencias Agropecuarias, Universidad Nacional de Córdoba, Av. Valparaíso s/n Ciudad Universitaria, Córdoba, Argentina; and V. C. Conci, Instituto de Fitopatología y Fisiología Vegetal, Instituto Nacional de Tecnología Agropecuaria (IFFIVE-INTA) Camino 60 cuadras km 5,5 (5119) Córdoba, Argentina

\begin{abstract}
Lunello, P., Di Rienzo, J., and Conci, V. C. 2007. Yield loss in garlic caused by Leek yellow stripe virus Argentinean isolate. Plant Dis. 91:153-158.

Garlic plants (Allium sativum) are naturally infected by a complex of viruses in the genera Potyvirus, Carlavirus, and Allexivirus. The yield of virus-free garlic plants (noninoculated control) was compared with that of plants infected with an Argentinean isolate of Leek yellow stripe virus (LYSV; L treatment) and garlic plants infected with the virus complex (VC). Evaluations were conducted in the field and in anti-aphid cages during two crop cycles after planting three sizes of cloves (categories). The percent plant emergence in the noninoculated control and in the $\mathrm{L}$ treatments (between 80 and 100\%) did not differ statistically, but the percent emergence for these two treatments was double that for the VC treatment (25 to 62\%). Plant height and leaf number in the $\mathrm{L}$ treatment were lower than in the noninoculated control during the first evaluation (year 1), but they did not differ during the second evaluation (year 2). However, both treatments produced taller plants with more leaves than those of VC in both years. The L treatment decreased bulb weight up to $28 \%$ and perimeter up to $9 \%$ when compared with those in the noninoculated control maintained in the anti-aphid cages until the end of the experiment. However, differences between these treatments were higher in the field experiments where plants were exposed to infection by other viruses (up to $36 \%$ in bulb weight and $13 \%$ in perimeter). Bulbs of the VC-infected plant treatment were reduced up to $74 \%$ in weight and $37 \%$ in perimeter. In field evaluations, a high percentage of plants were infected with Onion yellow dwarf virus (58 to $100 \%$ ), whereas fewer were infected with LYSV (15 to 68\%). Garlic virus A infection was high in plants previously infected with LYSV (96 and 97\%), but lower in the noninoculated control (12 and 68\%). These results show the high impact of the virus complex on garlic yield and the effect of LYSV as a component of the garlic virus complex.
\end{abstract}

Because of the exclusively asexual propagation of garlic (Allium sativum), systemic pathogens such as viruses persist over successive crop cycles, resulting in subsequent spread of the virus to different production regions. Garlic is mainly infected by multiple viruses of the Potyvirus, Carlavirus, and Allexivirus genera, which form a "viral complex" that causes garlic mosaic. The carlaviruses Shallot latent virus (SLV) and Garlic latent virus (synonymous with SLV, see Chen et al. [12]) have been recorded in European and Asian garlic $(1,11,12,22,42)$. Garlic common latent virus (GCLV) was detected in Asia, Europe, and America $(1,15,22,39)$. Different Allexivirus species have been identified in garlic, including Garlic virus $A, B, C, D, E$, and $X$, (GarV-A, B, C, D, and $X$ ) based on differences in their genomic sequences $(13,23,24,37,38,41)$.

Corresponding author: Vilma C. Conci

E-mail: vconci@correo.inta.gov.ar

Accepted for publication 7 September 2006.

DOI: 10.1094/PDIS-91-2-0153

(C) 2007 The American Phytopathological Society characterized $(28,30)$ was used in this study.

This paper reports the result of experiments to evaluate the effect of LYSV and the garlic virus complex on garlic yield after planting three different sizes of cloves in two crop cycles in the field. Plants were either exposed to natural infection with other garlic viruses or protected from other virus infection in anti-aphid cages.

\section{MATERIALS AND METHODS}

Virus isolation and transmission. LYSV, isolated from a leek plant with severe yellow stripe, was transmitted by aphids to virus-free leek seedlings (30). This Argentinean isolate was mechanically transmitted in $0.05 \mathrm{M}$ borate buffer $(\mathrm{pH}$ 8.1) with 300-mesh Carborundum to virusfree garlic plants obtained according to Conci and Nome (19) and tested as described below. After virus-free garlic plants were obtained, they were kept under anti-aphid cages and retested just before use.

Serological assays and antisera. Viral infection in the field treatments was evaluated by double-antibody sandwich enzymelinked immunosorbent assay (DAS-ELISA) according to Clark and Adams (14) with OYDV, LYSV, and GarV-A antisera from the stock at IFFIVE-INTA and obtained as described previously $(17,24,30)$.

The viruses in the originally virus-free garlic plants were analyzed by immunosorbent electron microscopy plus decoration (ISEM-D) according to Milne and Luisoni (32) with the following antisera: OYDV, LYSV, GarV-A, and an antiserum obtained from garlic plants infected with the viral complex that naturally infects garlic (Mix-antiserum). These antisera were from the stock at IFFIVE-INTA and obtained as described previously $(17,24$, 25,30). Brazilian antiserum was kindly provided by M. Carvalho from UFV, Vicosa, Brazil, and R. Shepherd from the University of California, Davis $(9,10)$. Although this antiserum was obtained from a mixture of viruses, in previous work it was shown to basically detect Allexivirus (V. Conci, unpublished results). OYDV antiserum was kindly provided by H. Lot and B. Delecolle from INRA, Montfavet, France; LYSV and SLV by L. Bos and D. Maat from the Research Insti- 
tute for Plant Protection, Wageningen, The Netherlands; GCLV and GarV-D by D. E. Lesemann, H. J. Vetten, and E. Barg, BBA from Braunschweig, Germany; and GarVC by S. Sumi from the Institute for Biotechnology Research, Wakunaga Pharmaceutical. Plants with questionable test results for potyviruses were analyzed by immunocapture reverse transcription-polymerase chain reaction (IC-RT-PCR) for OYDV and LYSV as described in Lunello et al. (29).

Plant material. Garlic cultivar BlancoIFFIVE, a white garlic type with a crop cycle of 210 to 230 days, was obtained from the Institute of Phytopathology and Plant Physiology of the National Agricultural Technology Institute (IFFIVE-INTA), Cordoba, Argentina. It is widely grown in the most important garlic production regions in Argentina.

Four different disease conditions or treatments were used: (i) Virus-free garlic plants (noninoculated control). These plants were obtained as described by Conci and Nome (19) and tested as mentioned above. The virological analyses were repeated just before the plants were used. (ii) Virus-free garlic plants inoculated with the LYSV-Arg. These plants were produced by mechanical inoculation and kept in antiaphid cages ( $\mathrm{L}$ treatment). Each plant was tested by ISEM-D to confirm the presence of the LYSV isolate before starting the experiments. (iii) Garlic plants were naturally infected with the garlic viral complex 4 years before starting the evaluations (VC 1). (iv) Garlic plants were naturally infected with the garlic viral complex 6 years before starting the evaluations (VC 2). To obtain VC 1 and 2, virus-free garlic plants were planted in the field next to infected garlic plants with the viral complex for 4 or 6 years, respectively, before starting the experiments. Plants used for the VC 1 and VC 2 treatments tested positive to OYDV, LYSV, and GarV-A antisera by DAS-ELISA; and GCLV and GarV-C antisera by ISEM-D.

One year before starting the evaluations, plants in the four treatments were planted in the same field under identical conditions, in individual anti-aphid cages for each treatment, in order to multiply the material and provide similar physiological conditions for the four treatments before starting the comparative yield evaluations. In the anti-aphid cages, separate cloves were planted every $10 \mathrm{~cm}$ in rows $30 \mathrm{~cm}$ apart. The disease condition of each treatment was tested again by DAS-ELISA and ISEM-D.

Experimental design. Two simultaneous experiments were conducted in the research field of IFFIVE-INTA in Córdoba, Argentina. One was conducted in the field, the other in anti-aphid cages. The experiments were repeated in the second year.

The size of cloves planted for each treatment was standardized using two sieves with openings of 1.5 and $1 \mathrm{~cm}^{2}$, resulting in three categories of clove size: large cloves (category 1), medium cloves (category 2), and small cloves (category 3 ). Three days prior to planting, cloves were disinfested by immersion for $15 \mathrm{~min}$ in a suspension of captan (Captan Tomen WP $80 \%, 25 \mathrm{~g}$ ), procymidone (Sumilex $50 \mathrm{SC}$ $50 \%, 15 \mathrm{~g}$ ), PCNB (pentachloronitrobenzene WP $78.2 \%, 15 \mathrm{~g}$ ), and benomyl (Benlate WP 50\%, $25 \mathrm{~g}$ ) in 25 liters of water.

Field experiments. The treatments were carried out as completely randomized split plots with eight replications for each year. Each plot was divided into three subplots, which were planted with 10 cloves of each category of clove size (large, medium, and small). The three subplots were planted at random within each plot. The experiment for each year contained 32 plots and 96 subplots, giving a total of 960 plants. The cloves were planted in furrows $60 \mathrm{~cm}$ apart at $15-\mathrm{cm}$ intervals.

Percent plant emergence was evaluated 15 days after planting, and plant height and leaf number were recorded 30 days after planting. Plants in the noninoculated control and $\mathrm{L}$ treatment were tested for virus using a DAS-ELISA with antisera for LYSV, OYDV, and GarV-A 30 days before harvest to determine the amount of new infection ("de novo" infection). Bulb weight and perimeter were measured 30 days after harvest. The perimeter of each harvested bulb was measured by using a thread around the greatest diameter of this bulb, and then the length of the thread was measured.

Anti-aphid cage experiments. The experiment was conducted as randomized split-plot designs with four replicates for each treatment. Each plot consisted of a separate anti-aphid cage containing 30 plants, 10 for each of the three clove sizes (categories). Subplots containing different clove sizes were distributed randomly within each cage. Sixteen cages $(1.5 \times 1 \times$ $1 \mathrm{~m})$ were used. The cloves were planted in three furrows $30 \mathrm{~cm}$ apart with $10 \mathrm{~cm}$ between cloves. A total of 480 cloves were planted. Weight and perimeter of the bulbs were measured 30 days after harvest. Viral sanitary conditions (L treatment, noninoculated control, and VC) were maintained for the different treatments until the end of the crop cycle and confirmed by DAS-ELISA throughout the crop cycle.

Cloves produced in anti-aphid cages the year before served as the planting material for the next year of treatments. Plants were fertilized conventionally with two applications of ammonium sulfate $(100 \mathrm{~kg} / \mathrm{ha}$ in each application).

Treatments effects were tested by analysis of variance according to a split-plot design. A posteriori comparisons between treatment means were carried out by a pairwise comparison method proposed by Di Rienzo et al. (21). We chose this method instead of Fisher-LSD or Duncan's multiple range tests, because it avoids the occurrences of overlapping groups of treatment means. The differences in yield among categories of clove sizes planted were evaluated as well as their interaction with the main treatments. Each year was analyzed separately. The level of significance was set at 5\%. Statistical analysis was carried out with InfoStat statistical software (Version 2003, Grupo InfoStat, Facultad Ciencias Agropecuarias, Universidad Nacional de Córdoba, Argentina).

\section{RESULTS}

Field experiments. Significant variation among treatments occurred with plant emergence $(P<0.0001)$. Plant emergence in the noninoculated control and L treatments did not differ significantly during the 2 years of the experiment, ranging from 80 to $100 \%$ in both treatments. The differences in emergence were significant between these treatments (noninoculated control and L) and VC 1 and VC 2, where emergence ranged from 25 to $62 \%$ (Table 1). No significant differences were observed among categories for noninoculated control and L treatments. Decreases in the percentage of emerged plants according to clove size planted (categories 1 to 3 ) in VC 2 treatments were detected (Table 1).

Significant differences among treatments were detected in plant height and number of leaves in the 2 years of evaluations $(P<0.0001)$. In year 1 , plant height and number of leaves differed significantly among the noninoculated control, L, and both VC treatments (VC 1 and VC 2$)(P<$ $0.0001)$. In year 2 , no significant differences were detected between noninoculated control and L treatment, but significant differences were recorded between these treatments (noninoculated control and L) and both VC treatments $(P<$ $0.0001)$. No differences were found between VC 1 and VC 2 during both years of experiments (Table 1). Plant height and number of leaves were related to categories of clove size planted $(P<0.0312)$; in most treatments, the bigger cloves planted yielded taller plants with more leaves (Table 1).

In the noninoculated control, infection by Potyvirus, OYDV, and LYSV was higher than $68 \%$ in year 1 . In year 2, $15 \%$ of the plants were infected with LYSV and $63 \%$ with OYDV in the noninoculated control. OYDV infected $99 \%$ of the plants in the $\mathrm{L}$ treatment during year 1 and $58 \%$ during year 2. Nearly all plants in the L treatment were infected by GarV-A (97 and $96 \%$ ), while the percentage was lower in the noninoculated control (12 and 68\%) during both years of treatments (Table 2).

Significant differences among treatments were detected in bulb weight and perimeter in the 2 years of evaluations $(P<$ $0.0001)$. In year 1 , bulb weight of the noninoculated control was significantly higher 
than in the $\mathrm{L}$ treatment $(P<0.0001)$; bulb weight decreased by 19,23 , and $36 \%$ for categories 1,2 , and 3 , respectively. In year 2 , bulb weight was not significantly lower in the $\mathrm{L}$ treatment than in the noninoculated control; only in category 1 $(14 \%)(P<0.0001)$ was it significantly lower. VC 1 and VC 2 treatments produced lighter bulbs than did the noninoculated control and $\mathrm{L}$ treatment. Bulb weights in the $\mathrm{VC}$ treatments were 38 to $65 \%$ lower than those in the noninoculated control. Statistically significant differences between VC 1 and VC 2 were detected in year 2 (Table 3 ).

Bulb perimeters significantly differed between noninoculated control and $\mathrm{L}$ treatment in year 1 , and were not significantly different in year 2 . Bulb perimeter decreased 4,5 , and $13 \%$ for categories 1 , 2 , and 3 , respectively, in year 1 , in the $\mathrm{L}$ treatment compared with the noninoculated control. The perimeter also decreased significantly in VC 1 and VC 2 treatments in relation to the noninoculated control and $\mathrm{L}$ treatment. The decreases in $\mathrm{VC}$ with respect to the noninoculated control ranged from 10 to $34 \%$ (Table 3). Significant difference in bulb perimeter was detected between VC 1 and VC 2 in year 2 .

When differences among clove size planted (categories) within each treatment were evaluated, losses in weight and perimeter of bulbs harvested gradually decreased in most cases with the size of the clove planted (from 1 to 3 ), although the difference was significant in some of them $(P<0.0017)$ (Table 3).

Anti-aphid cage experiments. Significant differences among treatments were detected in plant weight and perimeter in the evaluations $(P<0.0001)$. In bulb weight and perimeter, significant differences were detected between noninoculated control and $\mathrm{L}$ treatment in year 2, up to $28 \%$ in bulb weight and $9 \%$ in perimeter (Table 4).

Bulbs corresponding to noninoculated control and $\mathrm{L}$ treatment were heavier and wider than the ones corresponding to the
VC 1 and VC 2 treatments, which had losses from 42 to $69 \%$ in weight and 12 to $37 \%$ in perimeter, in relation to noninoculated control. Significant differences in weight and perimeter between VC 1 and VC 2 were detected in year 2 of evaluation (Table 4).

Among the categories of clove size planted, weight and perimeter of bulbs harvested decreased from 1 to $3(P<$ 0.0269); these decreases were statistically significant in some of the virus-infected treatments (L and VC treatments). No significant differences were observed among categories in virus-free plants (noninoculated control) (Table 4).

\section{DISCUSSION}

This is the first report of the effects of LYSV, independent of the virus complex, on garlic yield when the isolated virus was transmitted to virus-free garlic plants. In these evaluations, LYSV was analyzed in anti-aphid cages, where plants were infected with the same virus, without any additional viruses, until the end of the crop cycle. The treatment was also evaluated in a field where the plants were initially infected by the LYSV isolate and later exposed to natural virus contamination (de novo infection or new infection) during the crop cycle.

LYSV alone apparently had little effect on the plant. No decrease was detected in plant emergence in the $\mathrm{L}$ treatment in relation to the noninoculated control. Leaf number and plant height in the L treatment were significantly lower than in the noninoculated control in the first year, but no differences were found in year 2 . When the viral condition of the plants from each treatment in the anti-aphid cages was maintained until the end of the experiment, significant differences were detected in weight and perimeter of bulbs harvested between the noninoculated control and $\mathrm{L}$ treatment in year 1 (up to $28 \%$ in weight and $9 \%$ in perimeter). However, differences between these treatments were higher in the field experiments where plants were exposed to the infection with other viruses. Significant decreases ranged from $36 \%$ in bulb weight and $13 \%$ in perimeter. This could be attributed to the fact that plants in the field (not in cages) can achieve their highest yield potential, and thus differences between noninoculated control plants and L treatment are detectable. However, because plants in all treatments were infected with viruses in field experiments, the increased differences in yield also could be due to the interaction of LYSV with another virus. In Denmark, leek yellow stripe disease caused by LYSV was aggravated by an additional infection by Shallot latent virus (Carlavirus) (33). We observed that a high percentage of the plants from the $\mathrm{L}$ treatment were also infected with Allexivirus (GarV-A), which could indicate synergistic or additive effects between LYSV and Allexivirus. This assumption is supported in our experi-

Table 2. Percentage of garlic plants infected by Onion yellow dwarf virus (OYDV), Leek yellow stripe virus (LYSV), and Garlic virus A (GarV-A) in the field experiments

\begin{tabular}{|c|c|c|c|c|c|c|}
\hline \multirow[b]{4}{*}{ Treatment $^{\mathrm{z}}$} & \multicolumn{6}{|c|}{ Infected plants (\%) } \\
\hline & \multicolumn{3}{|c|}{ Year 1} & \multicolumn{3}{|c|}{ Year 2} \\
\hline & \multicolumn{3}{|c|}{ Antisera } & \multicolumn{3}{|c|}{ Antisera } \\
\hline & LYSV & OYDV & GarV-A & LYSV & OYDV & GarV-A \\
\hline $\begin{array}{l}\text { Noninoculated } \\
\text { control }\end{array}$ & 68 & 100 & 12 & 15 & 63 & 68 \\
\hline $\mathrm{L}$ & 100 & 99 & 97 & 91 & 58 & 96 \\
\hline
\end{tabular}

${ }^{\mathrm{z}}$ Treatments: noninoculated control, virus-free garlic plants; L, virus-free garlic plants inoculated with LYSV isolate by mechanical transmission and kept in anti-aphid cages until start of experiment.

Table 1. Effect of garlic viruses on mean emergence, height, and number of leaves of garlic plants that developed of each garlic virus treatment in first and second year of field experiments

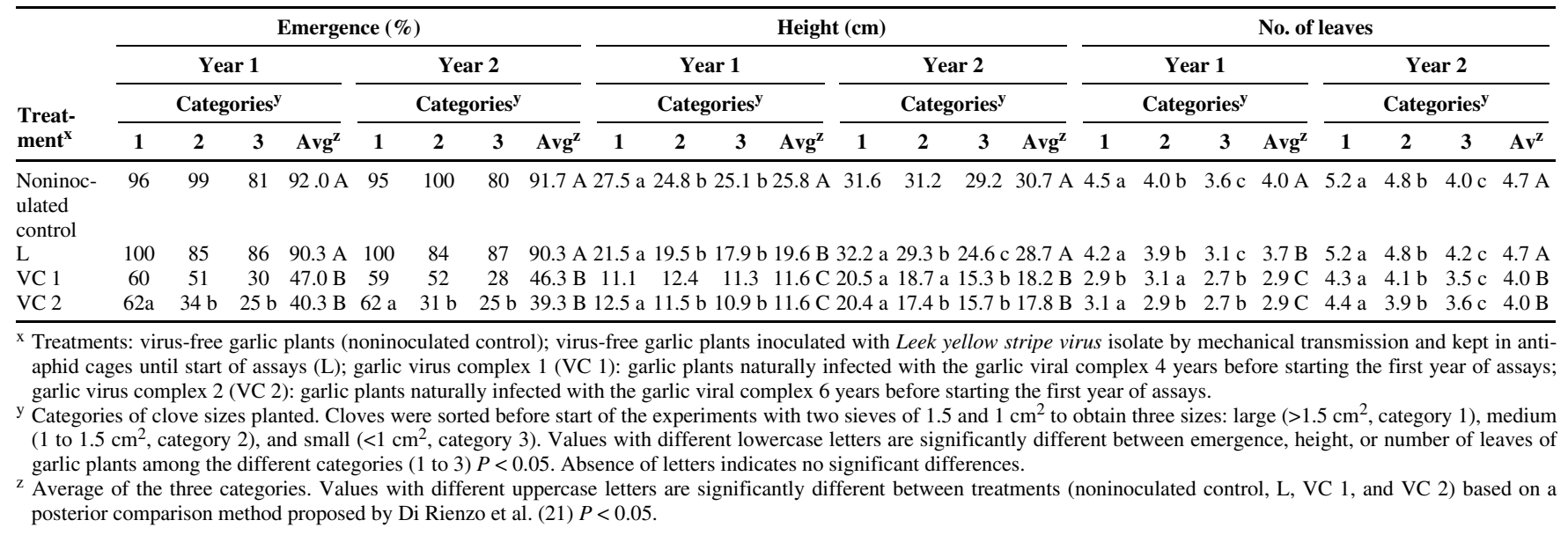


ments by the differences in yield detected in the field experiment between the noninoculated control and the $\mathrm{L}$ treatment where a high percentage of plants were infected with GarV-A (Tables 1 and 2). Viral infections with two or more viruses are common and have been reported often in plants. In some cases, these infections cause an increase in the accumulation of one or more viruses and in the differential expression of symptoms $(26,34,44)$. In potyvirus-associated synergistic diseases, host symptoms were much worse in plants infected with two viruses compared with those infected with one. This exacerbation of symptoms was correlated with increased accumulation of the nonpotyvirus, while the level of the potyvirus remained unchanged $(34,44)$. Some potyviruses, however, have been reported to enhance the titer of a luteovirus $(2,3)$ or potexvirus $(34,44)$, which can also act synergistically $(35,45)$. The difference in the percentage of GarV-A infection in noninoculated control in relation to the percentage infected with LYSV, a potyvirus (L treatment), could be due to the interaction of GarV-A with LYSV. The interaction between Potyvirus and Allexivirus has not been studied so far, but it warrants further investigation.

In the first year of field evaluation, the noninoculated control was statistically superior in weight and perimeter to the $\mathrm{L}$ treatment in all categories studied, but in the second year no difference was detected. Surprisingly, the noninoculated control had $12 \%$ new GarV-A infection during the first year compared with $68 \%$ during the second year (Tables 2 and 3). This change in the level of GarV-A infection suggests that the reduction of differences in weight and perimeter of cloves between noninoculated control and $\mathrm{L}$ treatment is due to the increase of GarV-A infection. Recently, studies of GarV-A (7) showing that this virus is responsible for important decreases in the garlic yield support this hypothesis.

The loss in bulb weight in the L treatment in both the anti-aphid cages $(18 \%$ in average of three categories) and the field ( $26 \%$ in average of three categories) is similar to the one observed by Lot et al. (27), who found a decrease of $17 \%$ in $\mathrm{cv}$.
Messidrome and 26\% in cv. Germidour. However, they found a loss of $54 \%$ in cv. Printanor, perhaps due to contamination with GCLV, which they reported for the LYSV treatment. This difference in percent damage could also be explained by a difference in the virulence of the LYSV isolate or in the susceptibility of the garlic cultivar. Studies on different LYSV isolates suggest the existence of intraspecific variability $(30,43)$, as occurs for other viral species with an RNA genome. Thus, different LYSV isolates or strains may cause different effects on yield.

For all the variables analyzed in this work-emergence of seedlings, height, leaf number of plants, weight and perimeter of bulbs - the noninoculated control produced higher means than those for plants infected with the viral complex (VC 1 and VC 2). Emergence tested 30 days after planting for the noninoculated control was double that for the VC treatments. Emergence was early and uniform in the noninoculated control treatment compared with the VC treatments (VC 1 and VC 2) with high infection of viruses. The early

Table 3. Effect of garlic viruses on mean weight and perimeter of garlic bulbs produced in 2 years of field experiments

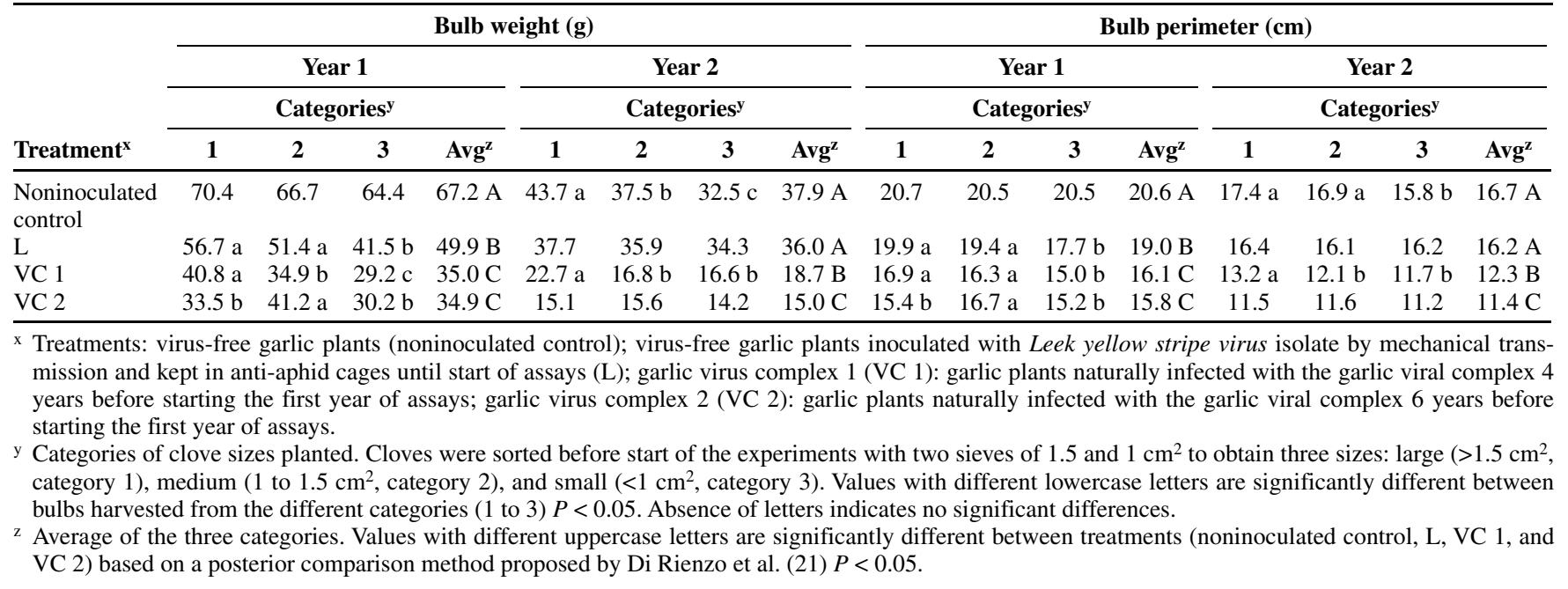

Table 4. Effect of garlic viruses on mean weight and perimeter of garlic bulbs produced in 2 years of anti-aphid cage experiments

\begin{tabular}{|c|c|c|c|c|c|c|c|c|c|c|c|c|c|c|c|c|}
\hline \multirow[b]{4}{*}{ Treatment $^{\mathrm{x}}$} & \multicolumn{8}{|c|}{ Bulb weight (g) } & \multicolumn{8}{|c|}{ Bulb perimeter $(\mathbf{c m})$} \\
\hline & \multicolumn{4}{|c|}{ Year 1} & \multicolumn{4}{|c|}{ Year 2} & \multicolumn{4}{|c|}{ Year 1} & \multicolumn{4}{|c|}{ Year 2} \\
\hline & \multicolumn{4}{|c|}{ Categories $^{y}$} & \multicolumn{4}{|c|}{ Categories $^{y}$} & \multicolumn{4}{|c|}{ Categories $^{\mathrm{y}}$} & \multicolumn{4}{|c|}{ Categories $^{y}$} \\
\hline & 1 & 2 & 3 & $\operatorname{Avg}^{\mathbf{z}}$ & 1 & 2 & 3 & $\operatorname{Avg}^{\mathbf{z}}$ & 1 & 2 & 3 & $\operatorname{Avg}^{\mathbf{z}}$ & 1 & 2 & 3 & $\operatorname{Avg}^{\mathbf{z}}$ \\
\hline $\begin{array}{l}\text { Noninocu- } \\
\text { lated control }\end{array}$ & 57.2 & 54.1 & 53.9 & $55.1 \mathrm{~A}$ & 59.2 & 53.6 & 60.1 & $57.6 \mathrm{~A}$ & 19.2 & 18.4 & 18.2 & $18.6 \mathrm{~A}$ & 18.3 & 17.8 & 18.1 & $18.1 \mathrm{~A}$ \\
\hline $\mathrm{L}$ & $63.4 \mathrm{a}$ & $49.1 \mathrm{~b}$ & $52.8 \mathrm{~b}$ & $55.1 \mathrm{~A}$ & 52.5 & 46.4 & 43.2 & $47.4 \mathrm{~B}$ & $19.6 \mathrm{a}$ & $17.9 \mathrm{~b}$ & $18.9 \mathrm{a}$ & $18.8 \mathrm{~A}$ & 17.6 & 16.9 & 16.4 & $17.0 \mathrm{~B}$ \\
\hline VC 1 & $32.5 \mathrm{a}$ & $23.6 \mathrm{~b}$ & $20.6 \mathrm{~b}$ & $25.6 \mathrm{C}$ & 24.0 & 23.1 & 18.7 & $21.9 \mathrm{C}$ & $16.3 \mathrm{a}$ & $14.7 \mathrm{~b}$ & $13.7 \mathrm{~b}$ & $14.9 \mathrm{~B}$ & 13.0 & 12.8 & 12.0 & $12.6 \mathrm{C}$ \\
\hline $\mathrm{VC} 2$ & $27.5 \mathrm{~b}$ & $31.1 \mathrm{a}$ & $26.9 \mathrm{~b}$ & $28.5 \mathrm{C}$ & 20.1 & 16.6 & 15.5 & $17.4 \mathrm{D}$ & 15.2 & 16.2 & 15.2 & $15.5 \mathrm{~B}$ & 12.3 & 11.7 & 11.4 & $11.8 \mathrm{D}$ \\
\hline
\end{tabular}

${ }^{\mathrm{x}}$ Treatments: virus-free garlic plants (noninoculated control); virus-free garlic plants inoculated with Leek yellow stripe virus isolate by mechanical transmission and kept in anti-aphid cages until start of assays (L); garlic virus complex 1 (VC 1): garlic plants naturally infected with the garlic viral complex 4 years before starting the first year of assays; garlic virus complex 2 (VC 2): garlic plants naturally infected with the garlic viral complex 6 years before starting the first year of assays.

${ }^{y}$ Categories of clove sizes planted. Cloves were sorted before start of the experiments with two sieves of 1.5 and $1 \mathrm{~cm}^{2}$ to obtain three sizes: large (>1.5 $\mathrm{cm}^{2}$, category 1$)$, medium (1 to $1.5 \mathrm{~cm}^{2}$, category 2$)$, and small $\left(<1 \mathrm{~cm}^{2}\right.$, category 3$)$. Values with different lowercase letters are significantly different between bulbs harvest from the different categories (1 to 3) $P<0.05$. Absence of letters indicates no significant differences.

${ }^{\mathrm{z}}$ Average of the three categories. Values with different uppercase letters are significantly different between treatments (noninoculated control, L, VC 1, and VC 2) based on a posterior comparison method proposed by Di Rienzo et al. (21) $P<0.05$. 
and uniform emergence of the plants in noninoculated control resulted in higher growth rates (because the plants start growing earlier) and allowed better handling of the crop and thus higher yields. Yield decreased in the VC treatments (VC 1 and $\mathrm{VC} 2$ ) up to $74 \%$ for bulb weight and $37 \%$ for perimeter, similar to the results obtained by other authors $(8,15,27,46)$.

There were no significant differences in plant emergence, height, or leaf number between the VC 1 and VC 2 treatments during the 2 years of the study (4 and 6 years of infection in the first year, and 5 and 7 years of infection in the second year). In the second year of field and antiaphid cage evaluations, bulb weight and perimeter in the VC 1 treatment were higher than in the VC 2 treatment as in our previous results (16), in which bulb weight and perimeter progressively declined throughout the successive crop cycles in field conditions conducive to infection. A marked decrease was found up to the third crop year, and then yield remained constant.

Comparing variables for yield by planting different sizes of cloves enabled us to observe differences in yields; larger cloves gave the highest yield, and yields progressively decreased in most of the cases as the clove size decreased. Heavier cloves are known to yield greater leaf area, which closely correlates with larger bulbs at harvest (M. Guiñazú, personal communication). Nevertheless, we did not detect statistically significant differences in yield with respect to the clove sizes planted (categories) in the noninoculated control in anti-aphid cages when there was no viral contamination. This could be due to the high conversion rate (relationship between size of cloves planted and size of bulbs harvested; M. Guiñazú, personal communication) in virus-free garlic plants (noninoculated control), which resulted in yields from small cloves equivalent to yields from large cloves. This is another important advantage of using virus-free garlic plants.

The results of these experiments demonstrated the importance of viruses in garlic production and emphasizes the need to control them. In this study, it was observed that LYSV alone does not produce great damage to yield, but in combination with other viruses, the effect was increased. The common situation in nature is garlic infection with a mixture of viruses, and they are responsible for great loss in the weight and perimeter of bulbs.

\section{ACKNOWLEDGMENTS}

This work was carried out with financial support from the National Institute of Agricultural Technology (INTA); National Council of Investigation, Science and Technology (CONICET); ArgentineanBrazilian Centre of Biotechnology (CABBIO); National Agency of Science and Technology Promotion (FONCyT); and the Córdoba Agency of Science. The authors thank D. Lesemann, H. J.
Vetten, and E. Barg from BBA, Braunschweig, Germany; L. Bos and D. Z. Maat from the Research Institute for Plant Protection, Wageningen, Netherlands; M. Carvalho and R. Shepherd from UFV, Vicosa, Brasil, and the University of California, Davis, USA; and S. Sumi, from the Institute for Biotechnology Research, Wakunaga Pharmaceutical for the antisera they provided, making this work possible.

\section{LITERATURE CITED}

1. Barg, E., Lesemann, D. E., Vetten, H. J., and Green, S. K. 1994. Identification, partial characterization and distribution of viruses infecting Allium crops in south and Southeast Asia. Acta Hortic. 358:251-258.

2. Barker, H. 1987. Invasion of non-phloem tissue in Nicotiana clevelandii by potato leafroll luteovirus is enhanced in plants also infected with potato Y potyvirus. J. Gen. Virol. 68:1223-1227.

3. Barker, H. 1989. Specificity of the effect of sap-transmissible viruses in increasing the accumulation of luteoviruses in co-infected plants. Ann. Appl. Biol. 115:71-78.

4. Bos, L. 1976. Onion yellow dwarf virus. C.M.I./A.A.B. Description of Plant Viruses No. 158.

5. Bos, L. 1981. Leek yellow stripe virus C.M.I./A.A.B. Descriptions of Plant Viruses No. 240.

6. Bos, L. 1982. Viruses and virus diseases of Allium species. Research Institute for Plant Protection. Acta Hortic. 127:11-29.

7. Cafrune, E. E., Perotto, C., and Conci, V. C. 2006. Effect of two Allexivirus isolates on garlic yield. Plant Dis. 90:898-904.

8. Canavelli, A., Nome, S., and Conci, V. C. 1998. Incidencia de las virosis en cultivos de ajo Rosado Paraguayo. Fitopatol. Bras. 23:354-358.

9. Carvalho, M. G. 1981. Viroses do alho. Fitopatol. Bras. 6:299-300.

10. Carvalho, M. G., Shepherd, R. R., and Hall, D. H. 1981. Virus em clone de alho sem sintomas e liberto do Garlic yellow stripe virus. Fitopatol. Bras. 6:236

11. Chen, J., Chen, J. P., and Adams, M. J. 2001. Molecular characterization of a complex mixture of viruses in garlic with mosaic symptoms in China. Arch. Virol. 146:1841-1853.

12. Chen, J., Chen, J. P., and Adams, M. J. 2002. Characterisation of some carla- and potyviruses from bulb crops in China. Arch. Virol. 147:419-428

13. Chen, J., Zheng, H. Y., Antoniw, J. F., Adams, M. J., Chen, J. P., and Lin, L. 2004. Detection and classification of Allexiviruses from garlic in China. Arch. Virol. 149:435-445.

14. Clark, M. F., and Adams, A. N. 1977. Characteristics of the microplate method of enzyme linked immunosorbent assay (ELISA) for the detection of plant viruses. J. Gen. Virol. 34:475-482.

15. Conci, V. C. 1997. Virus y fitoplasmas de ajo. Pages 267-291 in: 50 temas sobre producción de ajo, Vol. 3. J. L. Burba, ed. EEA-INTA La Consulta, Mendoza, Argentina.

16. Conci, V. C., Canavelli, A., Lunello, P., Di Rienzo, J., Nome, S. F., Zumelzu, G., and Italia R. 2003. Yield losses associated with virus infected garlic plants during five successive years. Plant Dis. 87:1411-1415.

17. Conci, V. C., Helguera, M., and Nome, S. F. 1999. Serological and biological comparison of Onion yellow dwarf virus from onion and garlic in Argentina. Fitopatol. Bras. 24:73-75.

18. Conci, V. C., Lunello, P, Buraschi, D., Italia, R., and Nome, S. F. 2002. Variations of Leek yellow stripe virus concentration in garlic and its incidence in Argentina. Plant Dis. 86:1085-1088.

19. Conci, V. C., and Nome, S. F. 1991. Virus free garlic (Allium sativum L.) plants obtained by thermotherapy and meristem tip culture. J.
Phytopathol. 132:186-192.

20. Delecolle, B., and Lot, H. 1981. Viroses de 1'ail. I-Mise en évidenceet essais de caractérisation par immunoélectronmicroscopie d'un complexe de trois virus chez defférentes populations d'ail atteintes de mosaïque. Agronomie 1:763-770.

21. Di Rienzo, J. A., Guzmán, A. W., and Casanoves, F. 2002. A multiple comparisons method based on the distribution of the root node distance of a binary tree. J. Agric. Biol. Environ. Stat. 7:1-14.

22. Dovas, C. I., Hatziloukas, E., Salomon, R., Barg, E., Shiboleth, Y., and Katis, N. I. 2001. Incidence of viruses infecting Allium spp. in Greece. Eur. J. Plant Pathol. 107:677-684.

23. Filho, P. A. M., Nagata, T., Dusi, A. N., Buso, J. A., Torres, A. C., Eiras, M., and Oliveira Resende, R. 2004. Detection of three Allexivirus species infecting garlic in Brazil. Pesq. Agropec. Bras. 39:735-740.

24. Helguera, M., Kobayashi, K., Bravo-Almonacid, F. F., Conci, V. C., and Mentaberry, A. N. 1997. Immunological detection of a GarV-type virus in Argentina garlic cultivars. Plant Dis. 81:10051010.

25. Helguera, M., Lunello, P., Nome, C., and Conci, V. C. 1997. Advances in the purification of filamentous viruses from garlic and in antisera production. Acta Hortic. 433:623-630.

26. Karyeija, R. F., Kreuze, J. F., Gibson, R. W., and Valkonen, J. P. T. 2000. Synergistic interactions of a Potyvirus and a phloem-limited Crinivirus in sweet potato plants. Virology 269:26-36.

27. Lot, H., Chevelon, V., Souche, S., and Dellecolle, B. 1998. Effects of Onion yellow dwarf virus and Leek yellow stripe virus on symptomatology and yield loss of three French garlic cultivars. Plant Dis. 82:1381-1385.

28. Lunello, P., Conci, V. C., Helguera, M., Laguna, G., and Nome, S. 1995. Identificación y producción de reactivos de diagnóstico para el Leek yellow stripe potyvirus (LYSV). Rev. For. Venezolana 1:78.

29. Lunello, P., Ducasse, D., and Conci, V. C. 2005. Improved PCR detection of potyviruses in Allium species. Eur. J. Plant Pathol. 112:371-378.

30. Lunello, P., Ducasse, D., Helguera, M., Nome, S. F., and Conci, V. C. 2002. An Argentinean isolate of Leek yellow stripe virus from leek can be transmitted to garlic. J. Plant Pathol. 84:11-17

31. Melhus, I. E., Reddy, C., Shenderson, W. J., and Vestal, E. 1929. A new virus disease epidemic on onions. Phytopathology 19:73-77.

32. Milne, R. G., and Luisoni, E. 1977. Rapid immune electron microscopy of virus preparations. Pages 265-281 in: Methods in Virology, Vol. 6. K. Maramorosch and H. Koprowski, eds. Academic Press, New York.

33. Paludan, N. 1980. Virus attack on leek: Survey, diagnosis, tolerance of varieties and winter hardiness. Tidsskr. Planteavl. 84:371-385.

34. Rochow, W. F., and Ross, F. 1955. Virus multiplication in plants doubly infected by potato viruses $\mathrm{X}$ and $\mathrm{Y}$. Virology 1:10-27.

35. Savenkov, E. I., and Valkonen, J. P. T. 2001 Potyviral helper-component proteinase Expressed in transgenic plants enhances titers of Potato leaf roll virus but does not alleviate its phloem limitation. Virology 283:285-293.

36. Schubert, J. 1995. Leek yellow stripe potyvirus. EMBL accession number X89711.

37. Song, S. I., Song, J. T., Chang, M. U., Lee, J. S., and Choi, Y. D. 1997. Identification of one of the major viruses infecting garlic plants, garlic virus X. Molecular Cells 7:705-709.

38. Sumi, S., Tsuneyoshi, T., and Furutani, H. 1993. Novel rod-shaped viruses isolated from garlic, Allium sativum, possessing a unique genome organization. J. Gen. Virol. 74:18791885 
39. Tsuneyoshi, T., Matsumi, K. T., Deng, T. C., Sako, I., and Sumi, S. 1998. Differentiation of Allium carlaviruses isolated from different parts of the world based on the viral coat protein sequence. Arch. Virol. 143:1093-1107.

40. Tsuneyoshi, T., Matsumi, K. T., and Sumi, S. 1998. Nucleotide sequence analysis of virus isolates indicates the presence of three Potyvirus species in Allium plants. Arch. Virol. 143:97-113.

41. Tsuneyoshi, T., and Sumi, S. 1996. Differentia- tion among garlic viruses in mixed infections based on RT-PCR procedures and direct tissue blotting immunoassays. Phytopathology 86:253-259.

42. Van Dijk, P. 1993. Carlavirus isolates from cultivated Allium species represent three viruses. Neth. J. Plant Pathol. 99:233-257.

43. Van Dijk, P. 1993. Survey and characterization of potyviruses and their strains of Allium species. Neth. J. Plant Pathol. 99:1-48.

44. Vance, V. B. 1991. Replication of potato virus
$\mathrm{X}$ RNA is altered in coinfections with potato virus Y. Virology 182:486-494.

45. Voinnet, O., Pinto, Y. M., and Baulcombe, D. C. 1999. Suppression of gene silencing: A general strategy used by diverse DNA and RNA viruses of plants. Proc. Natl. Acad. Sci. USA 96:14147-14152.

46. Walkey, D. G. A., and Antill, D. N. 1989 Agronomic evaluation of virus-free and virus infected garlic (Allium sativum L.). J. Hortic. Sci. 64:53-60 